\title{
Protease Inhibitor Resistance Mutations in Untreated Brazilian Patients Infected with HCV: Novel Insights about Targeted Genotyping Approaches
}

\author{
Isabel M.V.G. de Carvalho, ${ }^{1,2}$ Rafael Alves, ${ }^{2}$ Polyana A. Vasconcelos-Medeiros de Souza, ${ }^{1}$ \\ Edvaldo F. da Silva, ${ }^{3}$ Daniel Mazo, ${ }^{3}$ Flair J. Carrilho, ${ }^{3}$ Artur T.L. Queiroz, ${ }^{4 *}$ \\ and Mário G. Pessoa ${ }^{3}$ \\ ${ }^{1}$ Viral Imunology, Butantan Institute, Avenida Doutor Vital Brasil, São Paulo, Brazil \\ ${ }^{2}$ Applied Molecular Hepatology Laboratory (LHeMA), Hepatitis Sector, Gastroenterology Division, \\ São Paulo Federal University, São Paulo, Brazil \\ ${ }^{3}$ Department of Gastroenterology, University of São Paulo School of Medicine, São Paulo, Brazil \\ ${ }^{4}$ Immunoparasitology Laboratory, Gonçalo Moniz Research Center (FIOCRUZ), Salvador, BA, Brazil
}

Several new direct-acting antiviral (DAA) drugs are being developed or are already approved for the treatment of chronic hepatitis $C$ virus (HCV) infection. HCV variants presenting drugresistant phenotypes were observed both in vitro and during clinical trials. The aim of this study was to characterize amino acid changes at positions previously associated with resistance in the NS3 protease in untreated Brazilian patients infected with HCV genotypes 1a and 1b. Plasma samples from 171 untreated Brazilian patients infected with HCV were obtained from the Department of Gastroenterology of Clinics Hospital (HCFMUSP) in São Paulo, Brazil. Nested PCR and Sanger sequencing were used to obtain genetic information on the NS3 protein. Bioinformatics was used to confirm subtype information and analyze frequencies of resistance mutations. The results from the genotype analysis using non-NS3 targeted methods were at variance with those obtained from the NS3 protease phylogenetic analyses. It was found that $7.4 \%$ of patients infected with HCV genotype 1a showed the resistance-associated mutations V36L, T54S, Q80K, and R155K, while $5.1 \%$ of patients infected with HCV genotype $1 \mathrm{~b}$ had the resistance-associated mutations V36L, Q41R, T54S, and D168S. Notably, codons at positions 80 and 155 differed between samples from Brazilian patient used in this study and global isolates. The present study demonstrates that genotyping methods targeting the NS3 protein showed a difference of results when compared to mainstream methodologies (INNO-LiPA and polymerase sequencing). The resistance muta- tions present in untreated patients infected with HCV and codon composition bias by geographical location warrant closer examination. J. Med. Virol. 86:1714-1721, 2014. (C) 2014 Wiley Periodicals, Inc.

\section{KEY WORDS: HCV; hepatitis C; protease inhi- bitors; resistance; genotyping}

\section{INTRODUCTION}

The large number of individuals infected with hepatitis C virus (HCV) around the world is a major public health problem. Approximately $3 \%$ of the world population are infected [Pybus et al., 2001], and several aspects such as an asymptomatic acute phase [Farci et al., 2000] and low rates of sustained virologic response highlight the severity of the HCV epidemic. The standard treatment of pegylated interferon (PEG-INF) plus Ribavirin produces sustained virologic response in approximately $40-50 \%$ of patients infected with HCV genotype 1 and about $80 \%$ of patients infected with genotypes 2 and 3 [Manns

Grant sponsor: FAPESP; Grant numbers: 2009/14277-9; 2012/ 18168-2; Grant sponsor: CAPES (Brazil).

The authors declare no competing interests.

*Correspondence to: Artur T.L. de Queiroz, Rua Waldemar Falcão, 121, Candeal, Salvador, Bahia, Brazil.

E-mail: artur.queiroz@bahia.fiocruz.br

Accepted 9 June 2014

DOI 10.1002/jmv.24015

Published online 11 July 2014 in Wiley Online Library (wileyonlinelibrary.com). 
et al., 2001; Hadziyannis et al., 2004]. In addition to sub-optimal sustained virological response, this approach produces side effects associated with treatment dropout in a significant proportion of patients [Kowdley, 2005]. New drugs targeting essential viral replication factors were designed to decrease side effects and improve sustained virological response rates. Collectively referred to as direct acting antivirals (DAAs), these drugs inhibit directly the serine protease NS3 and the RNA-dependent RNA polymerase NS5B. Other targeted drugs, such as NS5A and P7 inhibitors, are still in development [Gao et al., 2010; Vermehren and Sarrazin, 2011].

Two new inhibitors, Telaprevir and Boceprevir, were recently approved for the treatment of hepatitis C genotype 1 [Poordad et al., 2011; Liapakis and Jacobson, 2012]. Other protease inhibitors such BI201335, TMC-435, mericitabine (RG7128), and Filibuvir showed promising results in recent clinical trials [Le Pogam et al., 2010; Lenz et al., 2010; Lemke et al., 2011]. The sustained virological response rate for triple therapy using PEG-INF plus Ribavirin and protease inhibitors (Telaprevir or Boceprevir) was greater than $70 \%$ in one population that was studied [Chary and Holodniy, 2010].

$\mathrm{HCV}$ is classified phylogenetically into seven genotypes with several subtypes (1a, 1b, 2a, etc.) due to high mutation rates [Simmonds et al., 2005; Gottwein et al., 2009]. As stated earlier, the PEG-INF plus Ribavirin sustained virological response rate is genotype-dependent [Qureshi et al., 2009]. The action of first-generation protease inhibitors is also genotypedependent, primarily targeting genotype 1 . In addition, different drug response profiles are observed between subtypes within the same genotype [Thibeault et al., 2004; Cento et al., 2012].

The emergence of drug-resistant strains of $\mathrm{HCV}$ has resulted in the failure of many therapeutic strategies [Tong et al., 2008]. Such strains have been observed in in vitro assays as well as in clinical trials [Flint et al., 2009; McCown et al., 2009; Susser et al., 2009]. The NS3 mutations R155K and A156T were reported as high resistance mutations [Courcambeck et al., 2006]. Other NS3 mutations, however, have been associated with lower resistance levels [Welsch et al., 2008]. Thus, combined drug schedules are currently being used to treat HCV infection to counter the possibility of monotherapy failure due to the appearance of resistant variants [Thompson and McHutchison, 2009].

The presence of drug resistance-associated mutations in HCV, albeit at low frequencies, raises public health concerns. These mutations have been observed in several distinct isolates collected worldwide [Bartels et al., 2008; Bae et al., 2010]. Sanger sequencing underestimated resistance mutation frequency in a HCV quasispecies population, making an accurate assessment of prevalence difficult [Ninomiya et al., 2012]. High throughput methods revealed the existence of strains with low mutation frequency among quasispecies [Beerenwinkel and Zagordi, 2011]; however, the role of these strains in drug treatment failure remains poorly understood [Macalalad et al., 2012].

The objectives of this study were to characterize HCV subtypes by phylogenetic analysis of the NS3 protease sequence in samples from chronically HCVinfected untreated patients with protease inhibitors, in Brazil, and to assess resistance-associated mutation profiles for NS3 by targeted genotyping techniques.

\section{METHODS}

\section{Samples}

Plasma samples of 171 identified previously HCV 1a- and 1b-infected patients were obtained from the Department of Gastroenterology of Clinics Hospital (HCFMUSP; São Paulo, Brazil). The genotyping methodology targeted regions other than the NS3 regions as INNO-LiPA, $5^{\prime}$ UTR and Polymerase NS5B sequencing (no individual samples information could be acquired about the specific genotyping technique). The signed patient consent forms were approved by the hospital ethics board in accordance with the 1975 Declaration of Helsinki.

\section{DNA Extraction}

HCV RNA extractions were performed using the QIAamp Viral RNA Kit (Qiagen [Uniscience do Brasil], Sao Paolo, Brazil) from $140 \mu l$ of serum, according to manufacturer's recommendations.

\section{RT-PCR and PCR}

Reverse transcription reactions were performed with Superscript III Reverse Transcriptase (Life Technologies, Carlsbad, California, EUA) and random primers. The cycling steps for all primer sets were as follows: $65^{\circ} \mathrm{C}$ for $5 \mathrm{~min}, 25^{\circ} \mathrm{C}$ for $5 \mathrm{~min}, 54^{\circ} \mathrm{C}$ for $60 \mathrm{~min}$, and $70^{\circ} \mathrm{C}$ for $15 \mathrm{~min}$.

A two-step (nested) PCR protocol was used for the NS3 gene primer set (P1aF1/P1aR1 and $\mathrm{P} 1 \mathrm{bF} 1 /$ $\mathrm{P} 1 \mathrm{bR} 1$ for the first PCR reaction; $\mathrm{P} 1 \mathrm{aF} 2 / \mathrm{P} 1 \mathrm{aR} 2$ and $\mathrm{P} 1 \mathrm{bF} 2 / \mathrm{P} 1 \mathrm{bR} 2$ for the second reaction) [Peres-da-Silva et al., 2010]. The final volume for the first reaction was $50 \mu \mathrm{l}$, as follows: $5 \mu \mathrm{l} 10 \times$ PCR buffer $(600 \mathrm{mM}$ Tris- $\mathrm{SO}_{4}, \mathrm{pH} 8.9 ; 180 \mathrm{mM}$ ammonium sulfate); $2 \mu \mathrm{l}$ primer $(20 \mathrm{pmol} / \mu \mathrm{l}), 1.0 \mu \mathrm{l} \mathrm{dNTP}, 1.5 \mu \mathrm{l} \mathrm{MgSO}_{4}, 0.3 \mu \mathrm{l}$ Platinum Taq High Fidelity DNA Polymerase (Life Technologies), and $10 \mu \mathrm{l}$ cDNA. The steps of the reaction were as follows: $94^{\circ} \mathrm{C}$ for $30 \mathrm{sec} ; 35$ cycles at $94^{\circ} \mathrm{C}$ for $30 \mathrm{sec}, 56^{\circ} \mathrm{C}$ for $30 \mathrm{sec}, 68^{\circ} \mathrm{C}$ for $1 \mathrm{~min}$; final extension at $68^{\circ} \mathrm{C}$ for $10 \mathrm{~min}$.

The second reaction was performed under the same conditions, using $5 \mu \mathrm{l}$ of reaction product from the first PCR as the DNA template, with the steps as follows: $94^{\circ} \mathrm{C}$ for $30 \mathrm{sec} ; 35$ cycles at $94^{\circ} \mathrm{C}$ for $30 \mathrm{sec}$, $60^{\circ} \mathrm{C}$ for $30 \mathrm{sec}, 68^{\circ} \mathrm{C}$ for $45 \mathrm{sec}$; final extension at $68^{\circ} \mathrm{C}$ for $10 \mathrm{~min}$. 


\section{Sanger Sequencing}

PCR products were purified with illustra GFX PCR Purification Kit (GE Healthcare, Buckinghamshire, UK). Capillary electrophoresis sequencing was performed with ABI PRISM BigDye Terminator Cycle Sequencing Ready Reaction Kit (PE Applied Biosystems, Carlsbad, California, EUA) on an ABI PRISM 3100 automatic sequencer (PE Applied Biosystems) according to manufacturer's instructions. All sequences were recorded in GenBank under the accessions numbers KF011281-KF011451.

\section{Phylogenetic and Resistance-Associated Mutation Analysis}

Since samples were genotyped by methods targeting random viral genes, after sequencing, contigs were created with Phred/Phrap/Consed [Ewing and Green, 1998; Ewing et al., 1998; Gordon et al., 1998].

The sample contigs and 16 reference sequences (AF009606_1a, D90208_1b, AY05129_1c, D14853_1c, D00944_2a, D10988_2b, AB047639_2a, D50409_2c, D17763_3a, D49374 _3b, D28917_3a, Y11604_4a, Y13184_5a, Y12083_6a，D84262_6b e EF108306_7a) were aligned using MUSCLE [Ē̄gar, 2004]. The best substitution model was identified using ModelTest [Posada and Crandall, 1998]. A phylogenetic tree was estimated from a HKY DNA substitution model with 1,000 bootstrap replicates using Seaview 4.0 [Gouy et al., 2010].

Resistance-associated mutation analysis was performed with BioEdit 7.1.3 [Hall, 1999]. Nucleotide sequences were translated and DAA-resistance mutation frequencies were determined [Lin et al., 2005; Kim and Timm, 2008; Vermehren et al., 2012]. The resistance mutation profiles from the Brazilian patient population were compared to previously determined profiles from the Los Alamos database [Alves et al., 2013]. The amino acid composition for codons 80 and 155 from the Brazilian patient samples was determined. These positions were chosen due to high resistance (for codon 155) and the high mutant frequency observed in other studies of the HCV 1a genotype [Cento et al., 2012; Alves et al., 2013]. The wild-type codon was set as the most frequently represented codon in both populations.

\section{RESULTS}

\section{HCV Subtype Classification by Phylogenetic Analysis}

One hundred seventy-one sequences were obtained through Phred/Phrap screening. Previously, genotyping methods targeting other HCV regions as INNOLiPA, 5' UTR and Polymerase NS5B sequencing had identified 56 genotype $1 \mathrm{a}$ and 115 genotype $1 \mathrm{~b}$ samples.

Phylogenetic analysis was performed with 16 reference sequences. All samples clustered with genotype 1 as expected; however, some samples were identified as a subtype that was different from what was determined by previous genotyping analyses. Thus, two samples previously classified as subtype 1a clustered with genotype 1b, whereas four samples previously classified as genotype $1 \mathrm{~b}$ clustered with the 1a genotype. All clusters were statistically significant with a bootstrap value above $90 \%$ (Fig. 1).

\section{Identification of Resistance-Associated Mutations}

Resistance-associated mutation profiles differed according to genotype. $7.4 \%(4 / 54)$ of genotype 1a patients had the resistance-associated mutations V36L, T54S, Q80K, and R155K, while 5.1\% (6/117) of genotype $1 \mathrm{~b}$ patients had the mutations V36L, Q41R, T54S, and D168S. Among genotype 1a patients, a single mutation was observed in each case, while for genotype $1 \mathrm{~b}$, the same mutations were detected on different cases (two T54S and three D168E; Table I).

The codon composition of resistance-associated mutations was also evaluated. In both subtypes, the V36L and T54S mutations required only one nucleotide substitution at the first position of the wild-type codon, defined as the most frequently observed codon. Q80K (subtype 1a) and Q41R (subtype 1b) also resulted from mutations in the first position of the wild-type codon. In contrast, the R155K (subtype 1a) and D168E (subtype 1b) mutations arose from substitutions as the second and third positions, respectively. The resistance-associated codon R155 had variations at the first and last positions of the wildtype codon sequence (AGA for subtype 1a and CGG for subtype $1 b$; Table II).

A comparison between sequences from global isolates obtained from the Los Alamos HCV sequence database [Cento et al., 2012] and those from the Brazilian patient samples used in this study revealed a difference in the R155 codon composition. Despite having similar genetic barriers, both required only one substitution to generate a resistance-associated mutation on subtype 1a (Los Alamos: $81.0 \%$ AGG; Brazil: 92.5\% AGA); two different codons were found in each group. Meanwhile, subtype $1 \mathrm{~b}$ had a profile similar to the previously reported in silico profile for CGG (Los Alamos: 87.3\%; Brazil: 79.4\%). The subtype 1b Q80 position was represented by similar frequencies of CAA (55.5\%) and CAG (41.8\%) in the Brazilian population (Fig. 2).

\section{DISCUSSION}

The development of new inhibitor drugs represents a significant advancement in HCV antiviral therapy. Despite the challenge posed by low mutation frequency quasispecies, these targeted drugs provide insights into the impact of resistant variants on viral replicative dynamics and the effects of protein mutations on sustained virological response and other treatment parameters. Clinical trials have already begun to elucidate the role of resistance mutations in 


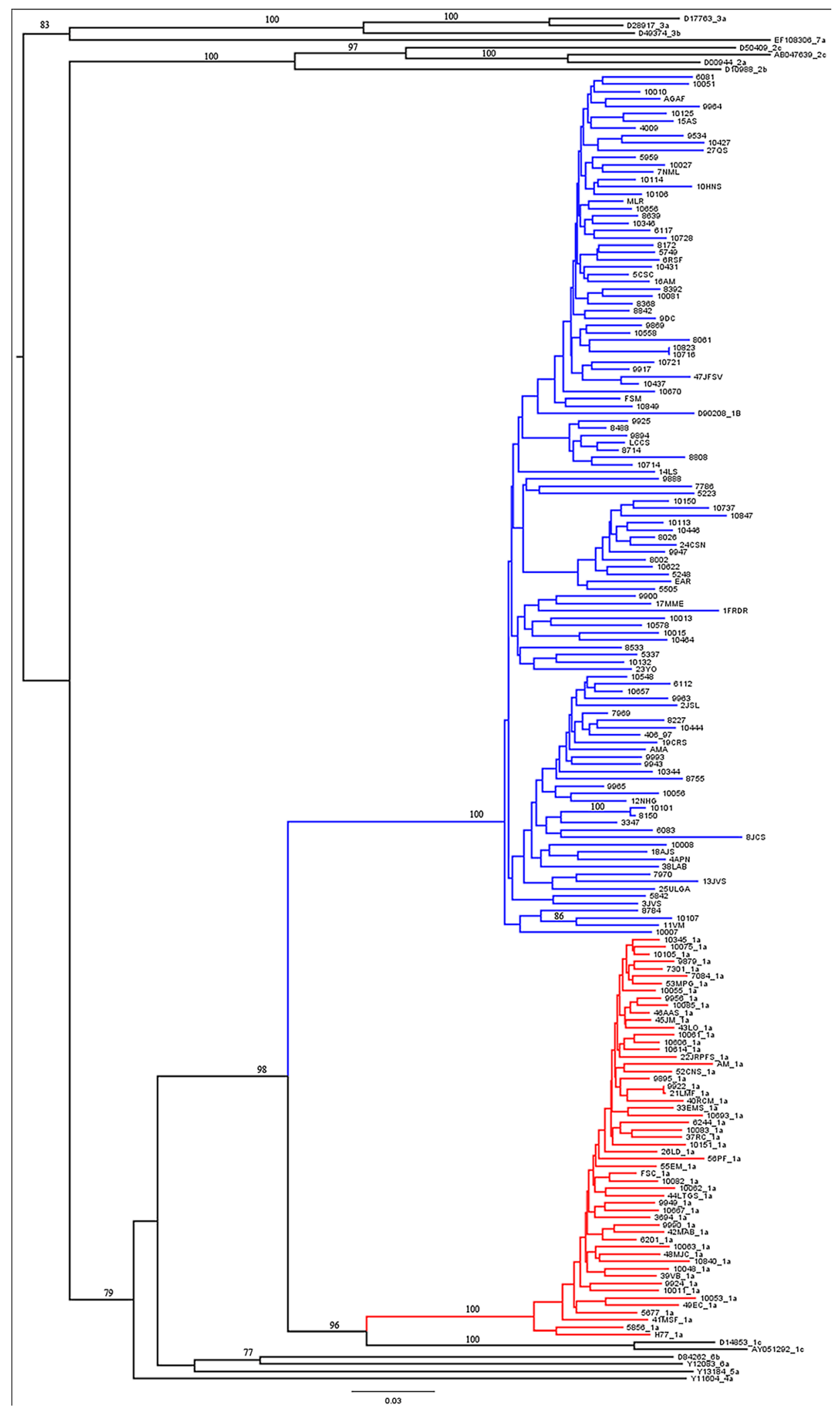

Fig. 1. Neighbor-joining phylogenetic tree reconstructed with sequences obtained from 171 HCV-infected patient samples (this work) and 16 reference sequences from the seven HCV genotypes obtained from the Los Alamos database. Genotype 1a sequences are in red and genotype $1 \mathrm{~b}$ sequences are in blue. Bootstrap values are placed above the branch that originated at each node. 
TABLE I. Amino Acid Frequency in the NS3 Protease at Select Positions Associated With Drug Resistance for Two Different HCV Genotypes

\begin{tabular}{|c|c|c|c|c|c|}
\hline Position & Reference strain $1 a^{*}$ & Reference strain $1 b^{* *}$ & Resistance mutation & $1 \mathrm{a}(\mathrm{n}=54)$ & $1 b(n=117)$ \\
\hline 36 & $\mathrm{~V}$ & $\mathrm{~L}$ & $\mathrm{~A} / \mathrm{M} / \mathrm{L} / \mathrm{G}$ & $\begin{array}{l}\mathrm{V}(53) \\
\mathrm{L}(1)\end{array}$ & $\begin{array}{c}\mathrm{V}(116) \\
\mathrm{L}(1)\end{array}$ \\
\hline 39 & $\mathrm{~A}$ & $\mathrm{~A}$ & $\mathrm{~V}$ & $\mathrm{~A}(54)$ & $\mathrm{A}(116) \mathrm{S}(1)$ \\
\hline 41 & $\mathrm{Q}$ & $\mathrm{Q}$ & $\mathrm{R}$ & $\mathrm{Q}(54)$ & $\begin{array}{c}\mathrm{Q}(116) \\
\mathrm{R}(1)\end{array}$ \\
\hline 43 & $\mathrm{~F}$ & $\mathrm{~F}$ & $\mathrm{~S} / \mathrm{C}$ & $\mathrm{F}(54)$ & $\mathrm{F}(117)$ \\
\hline 54 & $\mathrm{~T}$ & $\mathrm{~T}$ & $\mathrm{~A} / \mathrm{S}$ & $\begin{array}{c}\mathrm{T}(53) \\
\mathrm{S}(1)\end{array}$ & $\begin{array}{c}\mathrm{T}(115) \\
\mathrm{S}(2)\end{array}$ \\
\hline 80 & $\mathrm{Q}$ & $\mathrm{Q}$ & $\mathrm{K}$ & $\begin{array}{c}\mathrm{Q}(52) \\
\mathrm{K}(1) \mathrm{L}(1)\end{array}$ & $\begin{array}{c}\mathrm{Q}(114) \\
\mathrm{L}(3)\end{array}$ \\
\hline 109 & $\mathrm{R}$ & $\mathrm{R}$ & $\mathrm{K}$ & $\mathrm{R}(54)$ & $\begin{array}{c}\mathrm{R}(116) \\
\mathrm{S}(1)\end{array}$ \\
\hline 138 & $\mathrm{~S}$ & $\mathrm{~S}$ & $\mathrm{~T}$ & $\mathrm{~S}(54)$ & $\mathrm{S}(117)$ \\
\hline 155 & $\mathrm{R}$ & $\mathrm{R}$ & $\mathrm{K} / \mathrm{T} / \mathrm{I} / \mathrm{M} / \mathrm{G} / \mathrm{L} / \mathrm{S} / \mathrm{K} / \mathrm{T} / \mathrm{Q}$ & $\mathrm{R}(53) \mathrm{K}(1)$ & $\mathrm{R}(117)$ \\
\hline 156 & A & A & $\mathrm{S} / \mathrm{T} / \mathrm{V} / \mathrm{I}$ & $\mathrm{A}(54)$ & $\mathrm{A}(117)$ \\
\hline 168 & $\mathrm{D}$ & $\mathrm{D}$ & $\mathrm{A} / \mathrm{V} / \mathrm{E}$ & $\mathrm{D}(54)$ & $\begin{array}{c}\mathrm{D}(114) \\
\mathrm{E}(3)\end{array}$ \\
\hline 170 & I & I & $\mathrm{A}$ & $\begin{array}{l}\mathrm{I}(53) \\
\mathrm{V}(1)\end{array}$ & $\begin{array}{l}\mathrm{I}(52) \\
\mathrm{V}(65)\end{array}$ \\
\hline
\end{tabular}

${\mathrm{H} 77^{*}}$ genotype 1a (AF009606) and HPCJCG** genotype 1b (D90208) were the reference sequences. Amino acids in red are associated with protease inhibitor resistance.

treatment failure. These studies also provide a valuable means for determining mutation profiles associated with a particular drug based on in vivo and in vitro trials [Kim and Timm, 2008; Lenz et al., 2010; Fonseca-Coronado et al., 2012; Vermehren et al., 2012].

Effective genotyping methodologies would increase the useful information acquired from clinical trials. This study showed that genotyping methods that use other regions of the $\mathrm{HCV}$ genome resulted in the identification of genotypes differing from those obtained through the phylogenetic analysis of the drug target region of the NS3 protein [Larrat et al., 2013]. The six samples showing discordance between genotyping techniques were previously characterized with hepatitis $\mathrm{C}$ virus genotype assay (LiPA) 2.0 [Verbeeck et al., 2008]. This assay targets sequence information from $5^{\prime}$ UTR and core region. The genotyping based on $5^{\prime}$ UTR presents several limitations in differentiates $1 \mathrm{~b}$ and $1 \mathrm{a}$ genotype [Chen and Weck, 2002].

TABLE II. The NS3 Protease Codon Frequency at Select Positions Associated With Drug Resistance for Two Different Genotypes of HCV

\begin{tabular}{|c|c|c|c|c|c|c|}
\hline \multirow[b]{2}{*}{ Subtype } & \multicolumn{6}{|c|}{ Positions } \\
\hline & 36 & 39 & 41 & 43 & 54 & 80 \\
\hline \multirow[t]{4}{*}{$1 \mathbf{a}$} & GTG (50) & GCT (51) & CAG (49) & TTC (51) & ACT (44) & CAA (44) \\
\hline & GTA (3) & GCC (3) & CAA (5) & TTT (3) & TCT (1) & CAG (8) \\
\hline & CTG (1) & & & & $\mathrm{ACC}(9)$ & CTG (1) \\
\hline & & & & & & AAA (1) \\
\hline \multirow[t]{5}{*}{ 1b } & GTT (74) & GCA (50) & CAA (107) & TTC (113) & ACT (97) & CAA (65) \\
\hline & GTC (40) & GCC (3) & CAG (9) & TTT (4) & $\mathrm{ACA}(8)$ & CAG (49) \\
\hline & GTA (2) & TCA (1) & CGG (1) & & ACC (10) & CTG (2) \\
\hline & CTC (1) & & & & $\mathrm{TCT}(2)$ & CTA (1) \\
\hline & \multicolumn{6}{|c|}{ Positions } \\
\hline Subtype & 109 & 138 & 155 & 156 & 168 & 170 \\
\hline \multirow[t]{3}{*}{$1 \mathbf{a}$} & AGG (52) & TCC (51) & AGA (50) & GCC (51) & GAC (53) & ATC (53) \\
\hline & AGA (2) & TCT (3) & AGG (2) & GCT (3) & GAT (1) & $\mathrm{ATT}(1)$ \\
\hline & & & CGA (1) & & & \\
\hline \multirow{4}{*}{ 1b } & AGG (91) & TCT (107) & CGG (93) & GCT (99) & GAC (104) & ATA (52) \\
\hline & AGA (24) & TCC (9) & CGA (23) & GCC (17) & GAG (1) & GTA (38) \\
\hline & AGC (1) & TCA (1) & CGC (1) & GCA (1) & GAT (10) & GTG (27) \\
\hline & CGG (1) & & & & GAA (2) & \\
\hline
\end{tabular}

Codons in red encode amino acids associated with protease inhibitor resistance. 
A

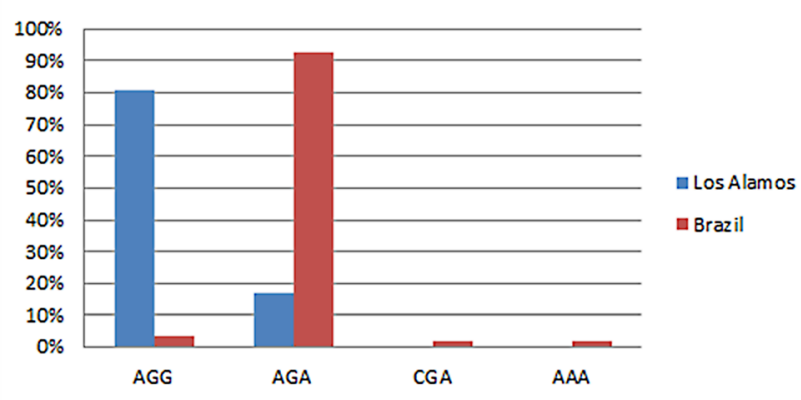

B

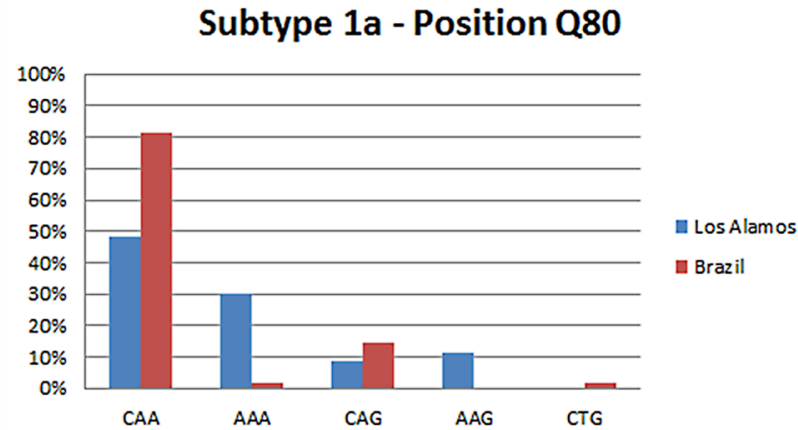

Subtype 1b - Position R155

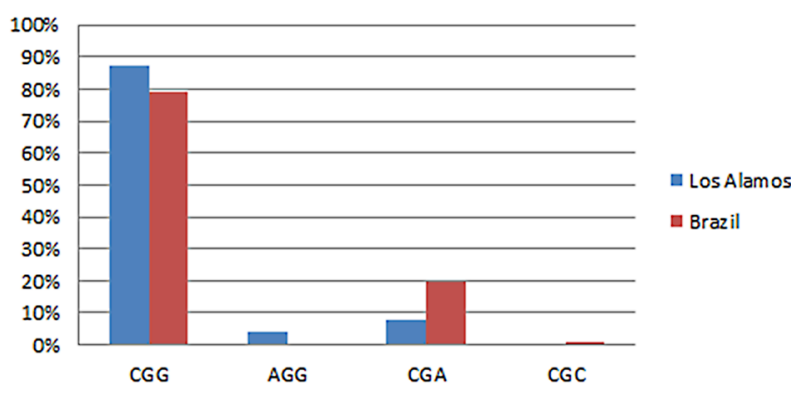

Subtype 1b - Position Q80

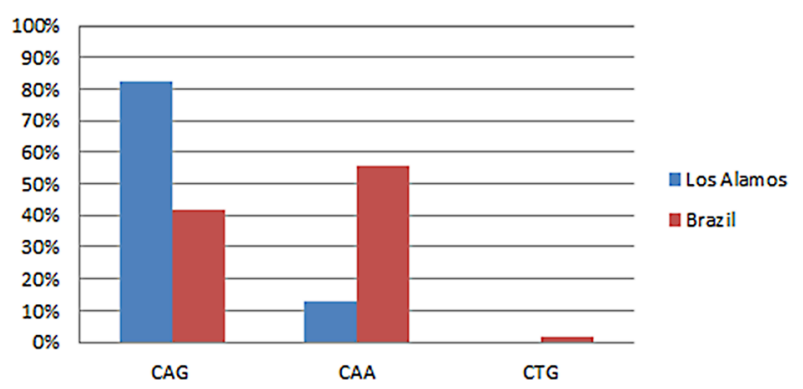

Fig. 2. Comparison of codon frequencies at positions 80 and 155 of the HCV NS3 protease in Brazilian patient sequences (this work), and global isolates from the Los Alamos HCV database (18).

Therefore, this discordance could be explained due this genotyping methodology limitation.

The classification of HCV genotypes based on mutation analysis is especially important in light of DAA resistance mutations in untreated patients infected, which raise concerns about the prognosis of these individuals [Bae et al., 2010; Peres-da-Silva et al., 2010; Fonseca-Coronado et al., 2012]. The high mutation rate of HCV is a likely explanation for the geographical bias and significant genetic differences observed within a subtype. This study has shown that the Q80 position is conserved and highly prevalent in the Brazilian population, compared to a previously characterized wild-type HCV on worldwide isolates [Cento et al., 2012]. The Q80K mutation (genotype 1a) had a frequency of $25-35 \%$ in global isolates [Paolucci et al., 2012], and of 1.8\% in Brazilian patient samples. Despite the few subtype 1a samples from this work, this difference was already reported in previous studies [Peres-da-Silva et al., 2010; Hoffmann et al., 2013; Lampe et al., 2013]. Low frequency strains are not detected by conventional sequencing method, thus leading to an underestimate of their significance in the development of resistance in HCV. The role of low resistance-associated mutation frequency in quasispecies remains poorly understood. New deep sequencing technologies with high throughput may be better suited to the detection of low frequency strains.
Low frequency mutations in quasispecies are nonetheless relevant to the emergence of drug-resistance in $\mathrm{HCV}$, because high virion production increases the frequency of the variant in the population. The identification of high resistance strains such as a subtype 1a strain harboring a R155K mutation, though present at a low frequency $(1.8 \%)$ raises questions about the actual mutation profile of the population.

The variation at codon 155 has been associated with specific effects on resistance in HCV. Several in vitro studies have correlated this amino acid substitution with a reduction in viral fitness; however, one study has demonstrated that the single mutant strain develops high resistance, leading to treatment failure [Shimakami et al., 2011]. Another study examined the relationship between a mutation at this codon and epitope expression, and found that this mutation promotes CD8 T-cell epitope escape [Salloum et al., 2010], providing an explanation for the persistence of HCV 2 years after the cessation of treatment [Colson and Gerolami, 2011].

Codon bias analysis of resistance-associated mutations revealed subtype specificity. Subtype 1a has a lower genetic barrier than subtype $1 \mathrm{~b}$ to the development of drug resistance, specifically at codon 155 . The most frequently occurring codon at this position (i.e., the wild-type codon) according to the Los Alamos sequence database requires only a single base substitution $(\mathrm{AGG} \rightarrow \mathrm{AAG})$ to confer drug resistance 
through an Arg to Lys mutation. Meanwhile, the subtype $1 \mathrm{~b}$ wild-type codon CGG, which is present both in Brazilian patient samples and global isolates requires at least two mutations to generate the same mutant codon. A single mutation in codon 155 in subtype 1a from Brazil is also sufficient to confer drug resistance $(\mathrm{AGA} \rightarrow \mathrm{AAA})$. Although there are two possible single base substitutions that can produce a mutant codon 155 (AGG to AAG and AGA to AAA in the Los Alamos and Brazilian populations, respectively), the genetic barrier is similar in these two geographically distinct populations. Finally, Q80K, a mutation associated with intermediate resistance to the drug TMC-435 was shown to occur at a high frequency in DAA untreated subtype 1a-infected patients, although the genetic barrier was similar in both subtypes.

The reasons for the discrepancy between the highmutation frequency observed in DAA untreated subtype 1a patients worldwide, and the low frequency observed in Brazilian patients remain unclear, given that the wild-type codon profiles are similar for both groups. The only difference between the two populations is that the resistance mutation occurs at a lower frequency in the Brazilian population. The low Q80K mutation frequency observed in our study population could be associated to geographical factors, as previous suggested by Hoffmann et al. [2013] and Peres-da-Silva et al. [2010].

HCV drug resistance studies have primarily focused on amino acid alterations in the NS3 protein. The present study, which examined codon profiles of untreated Brazilian HCV-infected patients in relation to global profiles, has identified geography as an important factor in the development of resistance in distinct populations. New molecular approaches should allow investigations of minority quasispecies populations. Nevertheless, consideration of the geographical characteristics of the major viral populations can contribute to the development of treatment protocols that are tailored to specific patient populations for improved therapy effectiveness.

\section{REFERENCES}

Alves R, Queiroz AT, Pessoa MG, da Silva EF, Mazo DF, Carrilho FJ, Carvalho-Filho RJ, de Carvalho IM. 2013. The presence of resistance mutations to protease and polymerase inhibitors in Hepatitis $\mathrm{C}$ virus sequences from the Los Alamos databank. J Viral Hepatitis 20:414-421.

Bae A, Sun SC, Qi X, Chen X, Ku K, Worth A, Wong KA, Harris J, Miller MD, Mo H. 2010. Susceptibility of treatment-naive hepatitis $\mathrm{C}$ virus (HCV) clinical isolates to HCV protease inhibitors. Antimicrob Agents Chemother 54:5288-5297.

Bartels DJ, Zhou Y, Zhang EZ, Marcial M, Byrn RA, Pfeiffer T, Tigges AM, Adiwijaya BS, Lin C, Kwong AD, Kieffer TL. 2008. Natural prevalence of hepatitis $\mathrm{C}$ virus variants with decreased sensitivity to NS3.4A protease inhibitors in treatment-naive subjects. J Infect Dis 198:800-807.

Beerenwinkel N, Zagordi O. 2011. Ultra-deep sequencing for the analysis of viral populations. Curr Opin Virol 1:413-418.

Cento V, Mirabelli C, Salpini R, Dimonte S, Artese A, Costa G, Mercurio F, Svicher V, Parrotta L, Bertoli A, Ciotti M, Di Paolo D, Sarrecchia C, Andreoni M, Alcaro S, Angelico M, Perno CF, Ceccherini-Silberstein F. 2012. HCV genotypes are differently prone to the development of resistance to linear and macrocyclic protease inhibitors. PLoS ONE 7:e39652.

Chary A, Holodniy M. 2010. Recent advances in hepatitis C virus treatment: Review of HCV protease inhibitor clinical trials. Rev Recent Clin Trials 5:158-173.

Chen Z, Weck KE. 2002. Hepatitis C virus genotyping: interrogation of the 5' untranslated region cannot accurately distinguish genotypes 1a and 1b. J Clin Microbiol 40:3127-3134.

Colson P, Gerolami R. 2011. Two years' persistence of naturally present substitution R155K within hepatitis C virus NS3 protease in the absence of protease inhibitor-based therapy. J Infect Dis 203:1341-1342, author reply 1342-1343.

Courcambeck J, Bouzidi M, Perbost R, Jouirou B, Amrani N, Cacoub P, Pèpe G, Sabatier JM, Halfon P. 2006. Resistance of hepatitis C virus to NS3-4A protease inhibitors: Mechanisms of drug resistance induced by $\mathrm{R} 155 \mathrm{Q}, \mathrm{A} 156 \mathrm{~T}, \mathrm{D} 168 \mathrm{~A}$ and D168V mutations. Antivir Ther 11:847-855.

Edgar RC. 2004. MUSCLE: Multiple sequence alignment with high accuracy and high throughput. Nucleic Acids Res 32:1792-1797.

Ewing B, Green P. 1998. Base-calling of automated sequencer traces using phred. II. Error probabilities. Genome Res 8:186194.

Ewing B, Hillier L, Wendl MC, Green P. 1998. Base-calling of automated sequencer traces using phred. I. Accuracy assessment. Genome Res 8:175-185.

Farci P, Shimoda A, Coiana A, Diaz G, Peddis G, Melpolder JC, Strazzera A, Chien DY, Munoz SJ, Balestrieri A, Purcell RH, Alter HJ. 2000. The outcome of acute hepatitis C predicted by the evolution of the viral quasispecies. Science 288:339-344.

Flint M, Mullen S, Deatly AM, Chen W, Miller LZ, Ralston R, Broom C, Emini EA, Howe AY. 2009. Selection and characterization of hepatitis $\mathrm{C}$ virus replicons dually resistant to the polymerase and protease inhibitors HCV-796 and boceprevir (SCH 503034). Antimicrob Agents Chemother 53:401-411.

Fonseca-Coronado S, Escobar-Gutierrez A, Ruiz-Tovar K, CruzRivera MY, Rivera-Osorio P, Vazquez-Pichardo M, Carpio-Pedroza JC, Ruiz-Pacheco JA, Cazares F, Vaughan G. 2012 Specific detection of naturally occurring hepatitis $\mathrm{C}$ virus mutants with resistance to telaprevir and boceprevir (protease inhibitors) among treatment-naive infected individuals. J Clin Microbiol 50:281-287.

Gao M, Nettles RE, Belema M, Snyder LB, Nguyen VN, Fridell RA Serrano-Wu MH, Langley DR, Sun JH, O'Boyle DR, Lemm JA Wang C, Knipe JO, Chien C, Colonno RJ, Grasela DM, Meanwell NA, Hamann LG. 2010. Chemical genetics strategy identifies an HCV NS5A inhibitor with a potent clinical effect. Nature 465:96-100.

Gordon D, Abajian C, Green P. 1998. Consed: A graphical tool for sequence finishing. Genome Res 8:195-202.

Gottwein JM, Scheel TK, Jensen TB, Lademann JB, Prentoe JC, Knudsen ML, Hoegh AM, Bukh J. 2009. Development and characterization of hepatitis $\mathrm{C}$ virus genotype 1-7 cell culture systems: Role of CD81 and scavenger receptor class B type I and effect of antiviral drugs. Hepatology 49:364-377.

Gouy M, Guindon S, Gascuel O. 2010. SeaView version 4: A multiplatform graphical user interface for sequence alignment and phylogenetic tree building. Mol Biol Evol 27:221-224.

Hadziyannis SJ, Sette H, Morgan TR, Balan V, Diago M, Marcellin P, Ramadori G, Bodenheimer H, Bernstein D, Rizzetto M Zeuzem S, Pockros PJ, Lin A, Ackrill AM, Group PIS. 2004. Peginterferon-alpha2a and ribavirin combination therapy in chronic hepatitis C: A randomized study of treatment duration and ribavirin dose. Ann Intern Med 140:346-355.

Hall TA. 1999. BioEdit: A user-friendly biological sequence alignment editor and analysis program for Windows 95/98/NT. Nucleics Acids Symp 41:95-98.

Hoffmann L, Ramos JA, Souza EV, Araujo Ramos AL, VillelaNogueira CA, Urmenyi TP, Tanuri A, Rondinelli E, Silva R. 2013. Dynamics of resistance mutations to NS3 protease inhibitors in a cohort of Brazilian patients chronically infected with hepatitis $\mathrm{C}$ virus (genotype 1 ) treated with pegylated interferon and ribavirin: A prospective longitudinal study. Virol J 10:57.

Kim AY, Timm J. 2008. Resistance mechanisms in HCV: From evolution to intervention. Expert Rev Anti Infect Ther 6:463478.

Kowdley KV. 2005. Hematologic side effects of interferon and ribavirin therapy. J Clin Gastroenterol 39:S3-S8. 
Lampe E, Lewis-Ximenez L, Espirito-Santo MP, Delvaux NM, Pereira SA, Peres-da-Silva A, Martins RM, Soares MA, Santos AF, Vidal LL, Germano FN, de Martinez AM, Basso R, Pinho JR, Malta FM, Gomes-Gouvea M, Moliterno RA, Bertolini DA, Fujishima MA, Bello G. 2013. Genetic diversity of $\mathrm{HCV}$ in Brazil. Antivir Ther 18:435-444.

Larrat S, Poveda JD, Coudret C, Fusillier K, Magnat N, SignoriSchmuck A, Thibault V, Morand P. 2013. Sequencing assays for failed genotyping with the versant hepatitis $\mathrm{C}$ virus genotype assay (LiPA) 2.0. J Clin Microbiol 51:2815-2821.

Le Pogam S, Seshaadri A, Ewing A, Kang H, Kosaka A, Yan JM, Berrey M, Symonds B, De La Rosa A, Cammack N, Najera I. 2010. RG7128 alone or in combination with pegylated interferon-alpha2a and ribavirin prevents hepatitis $\mathrm{C}$ virus (HCV) replication and selection of resistant variants in $\mathrm{HCV}$-infected patients. J Infect Dis 202:1510-1519.

Lemke CT, Goudreau N, Zhao S, Hucke O, Thibeault D, LlinasBrunet M, White PW. 2011. Combined X-ray, NMR, and kinetic analyses reveal uncommon binding characteristics of the hepatitis C virus NS3-NS4A protease inhibitor BI 201335. J Biol Chem 286:11434-11443.

Lenz O, Verbinnen T, Lin TI, Vijgen L, Cummings MD, Lindberg J, Berke JM, Dehertogh P, Fransen E, Scholliers A, Vermeiren K, Ivens T, Raboisson P, Edlund M, Storm S, Vrang L, de Kock H, Fanning GC, Simmen KA. 2010. In vitro resistance profile of the hepatitis $\mathrm{C}$ virus NS3/4A protease inhibitor TMC435. Antimicrob Agents Chemother 54:1878-1887.

Liapakis AM, Jacobson I. 2012. Telaprevir user's guide. Liver Int 32:17-25.

Lin C, Gates CA, Rao BG, Brennan DL, Fulghum JR, Luong YP Frantz JD, Lin K, Ma S, Wei YY, Perni RB, Kwong AD. 2005. In vitro studies of cross-resistance mutations against two hepatitis $\mathrm{C}$ virus serine protease inhibitors, VX-950 and BILN 2061. J Biol Chem 280:36784-36791.

Macalalad AR, Zody MC, Charlebois P, Lennon NJ, Newman RM, Malboeuf CM, Ryan EM, Boutwell CL, Power KA, Brackney DE, Pesko KN, Levin JZ, Ebel GD, Allen TM, Birren BW, Henn MR. 2012. Highly sensitive and specific detection of rare variants in mixed viral populations from massively parallel sequence data. PLoS Comput Biol 8:e1002417.

Manns MP, McHutchison JG, Gordon SC, Rustgi VK, Shiffman M, Reindollar R, Goodman ZD, Koury K, Ling M, Albrecht JK. 2001. Peginterferon alfa-2b plus ribavirin compared with interferon alfa-2b plus ribavirin for initial treatment of chronic hepatitis C: A randomised trial. Lancet 358:958-965.

McCown MF, Rajyaguru S, Kular S, Cammack N, Najera I. 2009. GT-1a or GT-1b subtype-specific resistance profiles for hepatitis $\mathrm{C}$ virus inhibitors telaprevir and $\mathrm{HCV}-796$. Antimicrob Agents Chemother 53:2129-2132.

Ninomiya M, Ueno Y, Funayama R, Nagashima T, Nishida Y, Kondo Y, Inoue J, Kakazu E, Kimura O, Nakayama K, Shimosegawa T. 2012. Use of illumina deep sequencing technology to differentiate hepatitis $\mathrm{C}$ virus variants. J Clin Microbiol 50:857-866.

Paolucci S, Fiorina L, Piralla A, Gulminetti R, Novati S, Barbarini G, Sacchi P, Gatti M, Dossena L, Baldanti F. 2012. Naturally occurring mutations to $\mathrm{HCV}$ protease inhibitors in treatmentnaive patients. Virol J 9:245.

Peres-da-Silva A, de Almeida AJ, Lampe E. 2010. Mutations in hepatitis C virus NS3 protease domain associated with resistance to specific protease inhibitors in antiviral therapy naïve patients. Arch Virol 155:807-811.
Poordad F, McCone J Jr, Bacon BR, Bruno S, Manns MP, Sulkowski MS, Jacobson IM, Reddy KR, Goodman ZD, Boparai N, DiNubile MJ, Sniukiene V, Brass CA, Albrecht JK, Bronowicki JP. 2011. Boceprevir for untreated chronic HCV genotype 1 infection. N Engl J Med 364:1195-1206.

Posada D, Crandall KA. 1998. MODELTEST: Testing the model of DNA substitution. Bioinformatics 14:817-818.

Pybus OG, Charleston MA, Gupta S, Rambaut A, Holmes EC, Harvey PH. 2001. The epidemic behavior of the hepatitis C virus. Science 292:2323-2325.

Qureshi S, Batool U, Iqbal M, Qureshi O, Kaleem R, Aziz H, Azhar M. 2009. Response rates to standard interferon treatment in HCV genotype 3a. J Ayub Med Coll Abbottabad 21:10-14.

Salloum S, Kluge SF, Kim AY, Roggendorf M, Timm J. 2010. The resistance mutation $\mathrm{R} 155 \mathrm{~K}$ in the NS3/4A protease of hepatitis $\mathrm{C}$ virus also leads the virus to escape from HLA-A*68-restricted CD8 T cells. Antiviral Res 87:272-275.

Shimakami T, Welsch C, Yamane D, McGivern DR, Yi M, Zeuzem S, Lemon SM. 2011. Protease inhibitor-resistant hepatitis C virus mutants with reduced fitness from impaired production of infectious virus. Gastroenterology 140:667-675.

Simmonds P, Bukh J, Combet C, Deléage G, Enomoto N, Feinstone S, Halfon P, Inchauspé G, Kuiken C, Maertens G, Mizokami M, Murphy DG, Okamoto H, Pawlotsky JM, Penin F, Sablon E, Shin-I T, Stuyver LJ, Thiel HJ, Viazov S, Weiner AJ, Widell A. 2005 . Consensus proposals for a unified system of nomenclature of hepatitis $\mathrm{C}$ virus genotypes. Hepatology 42:962-973.

Susser S, Welsch C, Wang Y, Zettler M, Domingues FS, Karey U, Hughes E, Ralston R, Tong X, Herrmann E, Zeuzem S, Sarrazin C. 2009. Characterization of resistance to the protease inhibitor boceprevir in hepatitis $\mathrm{C}$ virus-infected patients. Hepatology 50:1709-1718.

Thibeault D, Bousquet C, Gingras R, Lagace L, Maurice R, White PW, Lamarre D. 2004. Sensitivity of NS3 serine proteases from hepatitis $\mathrm{C}$ virus genotypes 2 and 3 to the inhibitor BILN 2061. J Virol 78:7352-7359.

Thompson AJ, McHutchison JG. 2009. Antiviral resistance and specifically targeted therapy for HCV (STAT-C). J Viral Hepat 16:377-387.

Tong X, Bogen S, Chase R, Girijavallabhan V, Guo Z, Njoroge FG, Prongay A, Saksena A, Skelton A, Xia E, Ralston R. 2008. Characterization of resistance mutations against HCV ketoamide protease inhibitors. Antiviral Res 77:177-185.

Verbeeck J, Stanley MJ, Shieh J, Celis L, Huyck E, Wollants E, Morimoto J, Farrior A, Sablon E, Jankowski-Hennig M, Schaper C, Johnson P, Van Ranst M, Van Brussel M. 2008. Evaluation of Versant hepatitis C virus genotype assay (LiPA) 2.0. J Clin Microbiol 46:1901-1906.

Vermehren J, Sarrazin C. 2011. New HCV therapies on the horizon. Clin Microbiol Infect 17:122-134.

Vermehren J, Susser S, Lange CM, Forestier N, Karey U, Hughes E, Ralston R, Tong X, Zeuzem S, Sarrazin C. 2012. Mutations selected in the hepatitis $C$ virus NS3 protease domain during sequential treatment with boceprevir with and without pegylated interferon alfa-2b. J Viral Hepat 19:120127.

Welsch C, Domingues FS, Susser S, Antes I, Hartmann C, Mayr G, Schlicker A, Sarrazin C, Albrecht M, Zeuzem S, Lengauer T. 2008. Molecular basis of telaprevir resistance due to V36 and T54 mutations in the NS3-4A protease of the hepatitis C virus. Genome Biol 9:R16. 